$14^{\text {th }}$ Conf. Agric. Develop. Res., Fac. of Agric., Ain Shams Univ.,

March, 2019, Cairo, Egypt

Special Issue, 27(1), 289 - 298, 2019

Website: http://strategy-plan.asu.edu.eg/AUJASCl/

\title{
GROWTH PARAMETERS, IRRIGATION REQUIREMENTS AND PRODUCTIVITY OF MAIZE IN RELATION TO SOWING DATES UNDER NORTH-DELTA OF EGYPT CONDITIONS
}

\author{
Hegab $^{1^{\star}}$, A.S.A., Fayed ${ }^{2}$, M.T.B., Maha, M.A. Hamada ${ }^{2}$ and \\ Abdrabbo', M.A.A.
}

1. Central Laboratory for Agricultural Climate (CLAC), Agriculture Research Center, Dokki, Giza, Egypt

2. Agronomy Dept., Fac. of Agric., Ain Shams Univ., P.O. Box 68 Hadyek Shoubra11241, Cairo, Egypt

*Corresponding author: Ahmedsabry1988@yahoo.com

Received 11 December, 2018,

Accepted 8 January, 2019

\section{ABSTRACT}

Field experiments were conducted in El-Bosaily farm in the Northern Coastal of Egypt during summer seasons of 2015 and 2016 to study the response of the single Cross 10 maize (Zea mays L.) hybrid to three sowing dates ( $1^{\text {st }}$ of May, $1^{\text {st }}$ of June and $1^{\text {st }}$ of July) and three levels of irrigation; $60 \%$, $80 \%$ and $100 \%$ of irrigation requirements (IR) which applied by drip irrigation system. The experimental design was split plot with four replications where the sowing dates and the irrigation levels were located in the main plots and the sub-plots, respectively. Germination percentage, vegetative growth, indices yield and yield components and water use efficiency were compared under the various sowing dates and irrigation level treatments. The main results were as follows: Vegetative growth traits, yield and water use efficiency of maize were decreased as sowing date delayed beyond the $1^{\text {st }}$ of May. Sowing maize seeds at $1^{\text {st }}$ of July gave the lowest vegetative growth traits and productivity compared to the other sowing dates during both seasons. Meanwhile application of $60 \%$ (IR) decreased vegetative growth traits as well as grain yield. Nevertheless, the $100 \%$ (IR) irrigation treatments gave the highest vegetative traits and grain yield. In contrary, results showed that the $60 \%$ (IR) irrigation requirement gave the highest water use efficiency (WUE). Increasing irrigation water above $60 \%$ (IR) led to decrease the values of water use efficiency. Meanwhile, the highest water use efficiency was obtained from the first sowing date $\left(1^{\text {st }}\right.$ May) followed by the second sowing date $\left(1^{\text {st }}\right.$ June) while the lowest value was obtained by the third sowing date $\left(1^{\text {st }}\right.$ July).

Key words: Maize (Zea mays L.), vegetative growth indices seed yield and its components and water use efficiency (WUE)

\section{INTRODUCTION}

Maize (Zea mays L.) is one of the most important cereal crops grown during the summer season in Egypt. It globally ranks the third position among cereal crops after wheat and rice (Gerpacio and Pingali, 2007). Increasing maize production became one of the most important goals of the Egyptian agricultural policy to face the human and animal demands. This could be achieved through imply the proper management systems which could improve its productivity (Medany et al 2009).

Sowing date is particularly important vital technical operation as it determines the timing of the crop cycles as well as the earliness of the crop harvesting, thus determines the length of the growing stages period according to growing degree days (Girardin, 1999). Climate associated with different sowing dates (sunshine duration, solar radiation, air temperature) have a direct effects on the growth and development of maize plants. Moreover, each maize hybrid has an optimum sow- 
ing date and the greater the deviation from this optimum (early or late sowing), the greater the yield loss (Abdrabbo et al 2013).

Medany et al (2007) stated that optimum temperature for maize growing is between 25 and $30^{\circ}$ C. Maize being a crop of tropical origin requires optimum temperature of $25^{\circ} \mathrm{C}$ for proper growth and development (Basu, 1999) and the prevailing sub-optimum temperatures affect the field emergence and early vegetative phase of the crop. Maize growth is affected adversely when temperature decreases to $5^{\circ} \mathrm{C}$ or increases beyond $32^{\circ} \mathrm{C}$ (Akbar et al 2008). Raising temperature $\left(+30^{\circ} \mathrm{C}\right)$ increases anthesis-silking interval and resulting in poor synchronization of flowering. Further increase in temperature reduces the pollen viability and silk receptivity resulting in poor seed set and yield reduction (Samuel et al 1986). Normally in Egypt, maize grows and yields at optimum date from the beginning of May to $1^{\text {st }}$ of June. Warmer temperature has generally a favorable effect on faster crop development. Campos et al (2004) expected significant yield losses in maize caused by drought/heat stress due to changing global climate.

Water management that maximize yield per unit of water consumed by plant is highly desired in Egypt (Ibrahim, 1999 and Gaber, 2000). Last decade, insufficient water supply for irrigation in many cultivated areas in Egypt is being the normal rather than the exception (Abdrabbo et al 2012). Therefore, it is necessary to improve irrigation management in these areas to shift from emphasizing production per unit area towards maximizing the production per unit of water consumed which is called water productivity (Hegab et al 2014). Water availability is the main yield limiting factor, where it is difficult to apply full crop water requirements to sustain maximal growth and yield (Abdrabbo et al 2013). Therefore it is very important to determine how to maintain optimum crop yields under limited irrigation conditions. Recently, this has stimulated the researchers to find new irrigation technologies, systems and irrigation strategies to improve water use efficiency. The application of regulated deficit irrigation strategies is one of the most promising methods to improve irrigation efficiency for major crops (Farag et al 2016). A second method involves the use of the modern irrigation systems, which improve the water application efficiency to the plant. Estimating the water consumptive use for field crops in the arid pant of Egypt under different irrigation methods may help in irrigation managements of the important crops (Phene, 1999).
The aim of this investigation was to study the effect of three planting dates and three irrigation levels on growth, yield components, seed yield and quality of maize yield to reveal the best combination between irrigation level and sowing date that can be recommended to increase maize yield uner Northern Coastal of Delta conditions.

\section{MATERIAL AND METHODS}

Field experiments were carried out at ElBosaily ( $31^{\circ} 40^{\prime} \mathrm{N}$; $30^{\circ} 40^{\prime} \mathrm{E}$ ), Protected Cultivation Experimental Farm, Central Laboratory for Agricultural Climate (CLAC), Agricultural Research Center $(\mathrm{ARC})$, at Behaira Governorate, in the Northern Coastal of Egypt. Experiments aimed to evaluate the effect of sowing dates, irrigation levels and their interaction on growth and yield of maize single cross 10 hybrid.

Data in Table (1) showed the measured climatic factors (maximum air temperature ${ }^{\circ} \mathbf{C}$ (Max. Temp.), minimum air temperature ${ }^{\circ} \mathbf{C}$ (Min. Temp.), Average relative humidity \% (Avg. $\mathrm{RH})$, average soil temperature ${ }^{\circ} \mathbf{C}$ (Avg ST $20 \mathrm{~cm}$.) and wind speed (Avg WS)(m/sec.) during the experimental period ( $1^{\text {st }}$ of May till mid of September during 2015 and 2016 seasons). These data collected from automated weather station of CLAC allocated at the experimental site.

The treatments comprised three sowing dates $\left(1^{\text {st }}\right.$ of May, $1^{\text {st }}$ of June, and $1^{\text {st }}$ of July of 2015 and 2016) and three irrigation levels $(0.60,0.80$ and 1.00 of IR). Calculations of irrigation levels were carried out whereas the irrigation control done via manual valves for each experimental plot. The first step to calculate the amount of irrigation water was to calculate evapotranspiration based on climatic data for farm location by FAO Penman method (Allen et al 1998). The potential evepotranspiration was calculated as follows:

$$
E T_{o}=\frac{0.408 \Delta\left(R_{n}-G\right)+\gamma \frac{900}{T+273} U_{2}\left(e_{s}-e_{a}\right)}{\Delta+\gamma\left(1+0.34 U_{2}\right)}
$$

$\mathrm{ET}_{\mathrm{o}}=$ reference evapotranspiration $\left(\mathrm{mm}_{\mathrm{day}}{ }^{-1}\right)$,

$\mathrm{Rn}=$ net radiation at the crop surface $\left(\mathrm{MJ} \mathrm{m}^{-2}\right.$ day $\left.{ }^{1}\right)$,

$\mathrm{G}=$ soil heat flux density $\left(\mathrm{MJ} \mathrm{m}^{-2}\right.$ day $\left.^{-1}\right)$,

$\mathrm{T}=$ mean daily air temperature at $2 \mathrm{~m}$ height $\left({ }^{\circ} \mathrm{C}\right)$,

$\mathrm{U}_{2}=$ wind speed at $2 \mathrm{~m}$ height $\left(\mathrm{m} \mathrm{s}^{-1}\right)$,

$\mathrm{e}_{\mathrm{s}}=$ saturation vapor pressure $(\mathrm{kPa})$,

$\mathrm{e}_{\mathrm{a}}=$ actual vapor pressure $(\mathrm{kPa})$, 

to Sowing Dates under North-Delta of Egypt Conditions

$\mathrm{e}_{\mathrm{s}}-\mathrm{e}_{\mathrm{a}}=$ saturation vapor pressure deficit $(\mathrm{kPa})$,

$\Delta=$ slope vapor pressure curve $\left(\mathrm{kPa}^{\circ} \mathrm{C}^{-1}\right)$, $\mathrm{Y}=$ psychrometric constant $\left(\mathrm{kPa}^{\circ} \mathrm{C}^{-1}\right)$.

The second step was to obtain values of daily irrigation water requirement by cubic meter per feddan according to the next equation (Doorenbos and Pruitt, 1977) and Keller and Bliesner (1990):

$\mathrm{IR}=\left(\mathrm{ET}_{\mathrm{o}}{ }^{*} \mathrm{~K}_{\mathrm{c}}\right)$ * $(1+\mathrm{LR}){ }^{*} 4.2 / \mathrm{Ea} \quad \ldots . . .\left(\mathrm{m}^{3} /\right.$ fed dan/ day)

Where:

$\mathrm{IR}=$ irrigation requirement for crop $\left(\mathrm{m}^{3} /\right.$ feddan/ day)

$\mathrm{K}_{\mathrm{c}}=$ Crop coefficient [dimensionless] .

$\mathrm{ET}_{0}=$ Reference crop evapotranspiration [mm/day].

$\mathrm{LR}=$ Leaching requirement LR (\%) (assumed $20 \%$ of the total applied water).

$\mathrm{Ea}=$ The efficiency of the irrigation system, (assumed $85 \%$ of the total applied water).

Table 1. Average monthly climatic data of ElBosaily location during the two studied seasons of 2015 \& 2016.

\begin{tabular}{|l|c|c|c|c|c|c|}
\hline \multicolumn{7}{|c|}{ First season (2015) } \\
\hline & Max. Temp. & Min. Temp. & Ave. RH & $\begin{array}{c}\text { Soil } \\
\text { Temp. }\end{array}$ & $\begin{array}{c}\text { Wind } \\
\text { Speed }\end{array}$ & ETo \\
\hline May & ${ }^{\circ}$ C & ${ }^{\circ} \mathbf{C}$ & $\%$ & ${ }^{\circ}$ C & m/sec. & mm/day \\
June & 27.02 & 14.64 & 74 & 23.69 & 0.79 & 4.49 \\
July & 28.57 & 17.21 & 80 & 26.54 & 0.92 & 4.77 \\
August & 30.63 & 19.20 & 82 & 28.94 & 0.77 & 4.99 \\
September & 31.78 & 20.31 & 81 & 30.22 & 0.61 & 4.39 \\
October & 28.63 & 18.63 & 81 & 29.31 & 0.44 & 3.46 \\
\hline \multirow{7}{*}{\begin{tabular}{l|l|c|c|c|c|c|} 
Second season (2016) \\
May
\end{tabular}} & 28.41 & 15.50 & 77.97 & 25.64 & 1.08 & 4.61 \\
June & 31.69 & 18.98 & 80.08 & 28.99 & 0.75 & 5.15 \\
July & 31.07 & 20.60 & 85.24 & 29.93 & 0.97 & 5.16 \\
August & 33.62 & 22.25 & 83.95 & 31.10 & 0.64 & 4.62 \\
September & 32.92 & 20.47 & 81.91 & 29.68 & 0.50 & 3.78 \\
October & 28.73 & 17.41 & 84.85 & 26.41 & 0.38 & 2.54 \\
\hline
\end{tabular}

The total amount of irrigation water was measured by water flow-meter for each treatment. Table (2) shows the seasonal water quantities for maize single cross 10 hybrid under different irrigation treatments for the three sowing dates at El-Bosaily site during the two seasons. Plants were irrigated by using drippers of $2 \mathrm{l} / \mathrm{hr}$ capacity. The chemical fertilizers were injected within irrigation water system.

Table 2. Seasonal drip irrigation quantities applied under different irrigation levels for maize single cross 10 hybrid under the experimental conditions of 2015 and 2016 seasons.

\begin{tabular}{|c|c|c|c|c|c|c|c|c|}
\hline Irrigation & \multicolumn{8}{|c|}{$\mathrm{m}^{3} /$ feddan/season } \\
\hline \multirow{2}{*}{ Sowing dates } & \multicolumn{4}{|c|}{ Season 1} & \multicolumn{4}{|c|}{ Season 2} \\
\hline & $60 \%$ & $80 \%$ & $100 \%$ & Mean & $60 \%$ & $80 \%$ & $100 \%$ & Mean \\
\hline $1^{\text {st }}$ May. & 1431 & 1908 & 2385 & 1908 & 1460 & 1947 & 2433 & 1947 \\
\hline $1^{\text {st }}$ June. & 1287 & 1716 & 2145 & 1716 & 1311 & 1748 & 2184 & 1748 \\
\hline $1^{\text {st }}$ July. & 1023 & 1363 & 1704 & 1363 & 1069 & 1425 & 1781 & 1425 \\
\hline Mean & 1247 & 1662 & 2078 & 1662 & 1280 & 1707 & 2133 & 1707 \\
\hline
\end{tabular}

Physical and chemical properties of the experiment's soil were analyzed before cultivation according to Chapman and Pratt (1961) and the results are tabulated in Tables (3-a and 3-b). The permanent wilting point (PWP) and field capacity (FC) of the trial soil were determined according to Israelsen and Hansen (1962) and presented in Table (3-a).

The experiment was designed in a split plot arrangement with four replications. Sowing dates were randomly distributed in the main plots, and irrigation levels allocated in the sub plots. Sub-Plot area was $15 \mathrm{~m}$ length $\times 3 \mathrm{~m}$ width, occupying an area of $45 \mathrm{~m}^{2}$. Plant distances were $0.30 \mathrm{~m}$ apart; the distances between rows were $0.70 \mathrm{~m}$. A distance of $2 \mathrm{~m}$ was left between each two irrigation treatments as a border among the treatments.

All other agriculture practices of maize cultivation were done in accordance with standard recommendations for commercial growers by the Ministry of Agriculture (Anonymous, 2015).

Germination percentage was recorded after 15 days of sowing and samples of ten plants of each experimental plot were taken after 75 days from sowing to estimate number of leaves /plant and leaf area index (LAI). At harvest plant height $(\mathrm{cm})$, weight of ears per plant $(\mathrm{g})$, weight of 100 grains (g) and grain yield (ton/fed) were determined from each plot. 
Table 3. Some physical and chemical analyses properties of the experimental soil at El-Bosaily site before cultivation.

Table 3.a. Physical analyses

\begin{tabular}{|c|c|c|c|c|c|c|c|}
\hline Soil & \multicolumn{7}{|c|}{ Physical properties } \\
\hline $\begin{array}{c}\text { Depth } \\
\text { cm }\end{array}$ & Sand \% & Clay\% & Silt \% & Texture & FC \% & PWP \% & $\begin{array}{c}\text { Bulk density } \\
\mathbf{g} / \mathbf{c m}^{\mathbf{3}}\end{array}$ \\
\hline $0-30$ & 96.41 & 3.30 & 0.29 & Sandy & 16.68 & 5.75 & 1.46 \\
\hline
\end{tabular}

Table 3.b. Chemical analyses

\begin{tabular}{|c|c|c|c|c|c|c|c|c|c|}
\hline $\mathrm{ECe}$ & \multirow{3}{*}{$\mathrm{pH}$} & \multicolumn{8}{|c|}{$\mathrm{meq} / \mathrm{I}$} \\
\hline \multirow[t]{2}{*}{ (Mmohs/cm) } & & \multicolumn{4}{|c|}{ Cations } & \multicolumn{4}{|c|}{ Anions } \\
\hline & & $\mathrm{Ca}^{++}$ & $\mathrm{Mg}^{++}$ & $\mathrm{Na}^{+}$ & $\mathrm{K}^{+}$ & $\mathrm{CO}_{3}^{--}$ & $\mathrm{HCO}_{3}^{-}$ & $\mathrm{Cl}^{-}$ & $\mathrm{SO}_{4}^{--}$ \\
\hline 1.58 & 7.74 & 3.2 & 2.3 & 8.0 & 1.3 & 0.0 & 1.3 & 9.0 & 4.4 \\
\hline
\end{tabular}

The water use efficiency (WUE) was calculated according to FAO (1982) as follows: The ratio of crop yield $(Y)$ to the total amount of irrigation water use in the field for the growth season (IR); WUE $\left(\mathrm{kg} / \mathrm{m}^{3}\right)=\mathrm{Y}(\mathrm{kg}) / \mathrm{IR}\left(\mathrm{m}^{3}\right)$. Water use efficiency and seasonal water consumption were determined after harvesting. Harvesting time was done at maturity symptoms according to sowing date and ranged between 111 days for early $\left(1^{\text {st }}\right.$ May) sowing date and 101 days for lately ( $1^{\text {st }}$ July) sowing ones.

Analysis of data was done, using SAS program for statistical analysis. The differences among means for all traits were tested for significance at 5\% level according to Waller and Duncan (1969). The combined analysis of variance for the data of the two seasons was performed after testing the error homogeneity. The differences among means were compared using the test of least significant difference (LSD) at 0.05 probability level.

\section{RESULTS AND DISCUSSIONS}

1- Effect of sowing dates and irrigation levels on germination $\%$ and vegetative growth traits.

Data in Tables from 4 to 7 illustrated the results of the influence of sowing dates, irrigation levels and their interaction on germination \% and vegetative growth traits (plant height, number of leaves per plant and leaf area index), of maize plant as a combined of the two growing seasons.

\section{(a) Germination percentage}

Statistical analysis of data the presented in Table (4) revealed that sowing dates, irrigation levels and their interactions exerted a significant effect on maize germination percentage. The greatest germination percentage $(\mathbf{9 4 . 6 1 \% )}$ was achieved for $1^{\text {st }}$ May sowing date followed by $1^{\text {st }}$ June $(89.61 \%)$ and finally $1^{\text {st }}$ July $(81.10 \%)$. Generally, the earlier of sowing date $1^{\text {st }}$ May was significantly better than other later sowing dates. Early sowing date ( $1^{\text {st }}$ May) furnished suitable environmental resources i.e climatic and edaphic factors to maize seeds to well germination and seedling establishment. These results trend agree with those obtained by Gesch and Archer (2005) Hegab et al (2014) and Oskouei et al (2014).

Regarding irrigation requirement (IR), 100\% irrigation level treatment gave the highest germination percentage followed by $80 \%$ of IR treatment; while $60 \%$ of irrigation requirement gave the lowest germination percentage. Such finding sustained that surrounding moisture conditions of each of $60 \%$ and $80 \%$ of IR treatments were not sufficient favorable to germinate maize seeds as a carbohydrates storage seeds. These results agree with those obtained by Farai et al (2015).

Regarding the interaction effect, data indicated that there were significant differences among germination values of the studied treatments. Early; sowing date combined by $100 \%$ irrigation level treatment gave the highest germination percentage $(\mathbf{9 7 . 3 9} \%)$ followed by first sowing date combined by $80 \%$ or irrigation requirement $(\mathbf{9 5 . 4 6 \% )}$ while the lowest germination percentage $\mathbf{( 7 7 . 2 8 \% )}$ was obtained by the late sowing date in the current study combined by $60 \%$ of irrigation requirement. These results trend agree with those obtained by by Russelle et al (1987) and Farai et al (2015). 
Table 4. Effect of sowing dates, irrigation levels and their interactions on germination percentage 15 days from sowing and plant height $(\mathrm{cm})$ of maize hybrid at harvest at El-Bosaily Farm, Behira Governorate, as a combined of 2015 and 2016 growing seasons.

\begin{tabular}{|c|c|c|c|c|c|c|c|c|}
\hline \multirow{4}{*}{ Sowing dates (D) } & \multicolumn{8}{|c|}{ Combined of the two growing seasons } \\
\hline & \multicolumn{8}{|c|}{$\begin{array}{c}\text { Irrigation levels (I) } \\
\end{array}$} \\
\hline & \multicolumn{4}{|c|}{ Germination percentage } & \multicolumn{4}{|c|}{ Plant height $(\mathrm{cm})$ at harvest } \\
\hline & $60 \%$ & $80 \%$ & $100 \%$ & Mean & $60 \%$ & $80 \%$ & $100 \%$ & Mean \\
\hline $1^{\text {st }}$ May & 90.99 & 95.46 & 97.39 & 94.61 & 232.9 & 254.8 & 264.4 & 250.7 \\
\hline $1^{\text {st }}$ June & 82.61 & 91.68 & 94.55 & 89.61 & 225.8 & 241.2 & 252.9 & 239.9 \\
\hline $1^{\text {st }}$ July & 77.28 & 80.38 & 85.66 & 81.10 & 221.8 & 231.4 & 244.4 & 232.5 \\
\hline Mean & 83.63 & 89.17 & 92.53 & 88.44 & 226.8 & 242.5 & 253.9 & 241.0 \\
\hline \multicolumn{9}{|c|}{ L.S.D $5 \%$} \\
\hline $\mathrm{D}$ & \multicolumn{4}{|c|}{1.78} & \multicolumn{4}{|c|}{5.25} \\
\hline 1 & \multicolumn{4}{|c|}{1.12} & \multicolumn{4}{|c|}{7.10} \\
\hline DI & \multicolumn{4}{|c|}{0.65} & \multicolumn{4}{|c|}{4.10} \\
\hline$D=$ sowing dates & = Irrigatio & levels & $\mathrm{Dl}=$ sow & g dates* & gation lev & & & \\
\hline
\end{tabular}

\section{(b) Vegetative growth characters}

Data presented in Tables (4 and 5) indicated that there were significant effects of sowing date and irrigation levels on plant height, number of leaves/plant and leaf area index (LAI) of maize plants. Regarding the effect of sowing date on plant height, number of leaves/plant and leaf area index (LAI) the early planting date $\left(1^{\text {st }}\right.$ of May) gave the highest values of plant height, number of leaves/plant and leaf area index (LAl); the second sowing date came in the second order; while the lowest plant height, number of leaves/plant and leaf area index (LAl) values were obtained by the lately sowing date ( $1^{\text {st }}$ of July). Early sowing date $\left(1^{\text {st }}\right.$ of May) performed suitable climate conditions and extending plant duration and thus improves vegetative growth traits of maize plant. These results trend agree with those obtained by ElMarsafawy et al (2012) whom confirmed that select appropriate maize hybrid with optimum sowing date led to achieve maximum growth and productivity of this hybrid. While, Abdrabbo et al (2013) mentioned that late sowing date decline the vegetative growth and productivity of maize hybrids in the Northern East of Delta.

Regarding irrigation requirement (IR), 100\% irrigation level gave the tallest maize plant followed by $80 \%$ of IR treatment; while $60 \%$ of irrigation requirement gave the shortest plant height. The number of leaves per plant and LAI had the same trend. Well-watered irrigation requirement level
( $100 \%$ of IR) stimulates number and size of plant cell and consequently increased height, number of green leaves and LAl values of maize plant. Similar trend was obtained by Abdrabbo et al (2013) who reported that the highest vegetative growth in both season were achieved form 100\% of irrigation water requirements. The same authors concluded that sufficient irrigation level may be necessary to face the water consumption by maize plant in summer season which led to increase photosynthesis process and nutrient uptake of plant. The same findings was obtained by (Beiragi et al 2011) who revealed that sufficient irrigation water led to increase in plant growth in comparison with deficit irrigation levels.

Regarding the interaction effect among sowing dates and irrigation requirement levels, data indicated that there were significant difference among the studied treatments; first sowing date combined by $100 \%$ irrigation level gave the highest values of plant height, number of leaves/plant and leaf area index (LAI) followed by first sowing date combined by $80 \%$ of irrigation requirement; the lowest plant height was obtained by the last sowing date in the current study combined by $60 \%$ of irrigation requirement. The same trend was obtained by Medany et al (2009). In this respect Babiker (1999) confirmed that using sufficient irrigation quantity, sowing in an appropriate sowing date as well as using proper hybrid led to increase maize growth rate. 
Table 5. Effect of sowing dates, irrigation levels and their interactions on number of leaves/plant and LAI of maize hybrid plant at El-Bosaily Farm, Behira Governorate, as a combined of 2015 and 2016 growing seasons.

\begin{tabular}{|c|c|c|c|c|c|c|c|c|}
\hline \multirow{4}{*}{$\begin{array}{l}\text { Sowing dates } \\
\text { (D) }\end{array}$} & \multicolumn{8}{|c|}{ Combined of the two growing seasons } \\
\hline & \multicolumn{8}{|c|}{$\begin{array}{l}\text { Irrigation levels (I) } \\
\end{array}$} \\
\hline & \multicolumn{4}{|c|}{ Number of leaves/plant } & \multicolumn{4}{|c|}{ Leaf area index (LAI) } \\
\hline & $60 \%$ & $80 \%$ & $100 \%$ & Mean & $60 \%$ & $80 \%$ & $100 \%$ & Mean \\
\hline $1^{\text {st }}$ May & 17.25 & 20.38 & 22.38 & 20.00 & 5.07 & 5.78 & 6.09 & 5.65 \\
\hline $1^{\text {st }}$ June & 15.19 & 17.13 & 18.94 & 17.09 & 3.66 & 4.28 & 4.91 & 4.28 \\
\hline $1^{\text {st }}$ July & 14.32 & 15.13 & 15.50 & 14.98 & 3.12 & 3.42 & 3.65 & 3.39 \\
\hline Mean & 15.59 & 17.54 & 18.94 & 17.36 & 3.95 & 4.49 & 4.88 & 4.44 \\
\hline \multicolumn{9}{|l|}{ L.S.D 5\% } \\
\hline D & \multicolumn{4}{|c|}{0.88} & \multicolumn{4}{|c|}{0.23} \\
\hline I & \multicolumn{4}{|c|}{0.76} & \multicolumn{4}{|c|}{0.26} \\
\hline $\mathrm{DI}$ & \multicolumn{4}{|c|}{0.44} & \multicolumn{4}{|c|}{0.15} \\
\hline
\end{tabular}

\section{2- Effect of sowing dates and irrigation levels on maize yield and yield components.}

Yield and yield components under investigation included: weight of ears per plant $(\mathrm{g})$, weight of 100 grains (g) and grain yield /fed (ton/fed.). Results of the influence of sowing dates, irrigation levels and their interactions on such traits are presented in Tables (6 and 7).

Data showed that weight of ears per plant $(\mathrm{g})$, weight of 100 grains (g) and grain yield /fed (ton/fed.) were significantly affected by sowing dates. It is worthy to mention that yield is the quantity of economical crop material harvested per plant or per unit land area. Also, vegetative growth exactly contributed in maximizing obtained yield. So, the effect of sowing date on vegetative characters reflects firstly on yield components and then on the harvested yield. Therefore, the influence of sowing dates on the obtained maize weight of ears per plant $(\mathrm{g})$, weight of 100 grains $(\mathrm{g})$ and grain yield /fed (ton/fed.) took the same trend of all the recorded yield attributes traits.

Results in Tables (6 and 7) cleared that the highest values of weight of ears per plant $(g)$, weight of 100 grains $(\mathrm{g})$ and grain yield /fed (ton/fed.) were obtained by the $1^{\text {st }}$ May sowing date followed by the $1^{\text {st }}$ June sowing date. The lowest weights of ears per plant (g), 100 grains (g) and grain yield /fed (ton/fed.) were obtained by the late sowing date $\left(\mathbf{1}^{\text {st }}\right.$ July) treatment.

In regard to irrigation levels the results indicated that $100 \%$ IR irrigation levels followed by $80 \%$ IR produced the highest weight of ears per plant (g), weight of 100 grains (g) and grain yield /fed (ton/fed.). However $60 \%$ IR treatment resulted the lowest ones.

Concerning the interaction effect between sowing dates and irrigation levels, data showed that the highest weight of ears per plant $(\mathrm{g})$, weight of 100 grains (g) and grain yield /fed (ton/fed.) were obtained by $100 \%$ of irrigation requirement combined with $1^{\text {st }}$ May sowing date followed by $80 \%$ of irrigation requirement with $1^{\text {st }}$ May sowing date. The lowest values of weight of ears per plant $(\mathrm{g})$, weight of 100 grains (g) and grain yield /fed (ton/fed.) were obtained by $60 \%$ of irrigation requirement with the $1^{\text {st }}$ July sowing date. The obtained results might be due to adequate soil moisture which create favorable conditions which led to increase availability and uptake of nutrients as well as higher photosynthesis process, which might reflected on higher number of leaves per plant and then produce higher weight of ears per plant $(\mathrm{g})$, weight of 100 grains (g) and grain yield /fed (ton/fed.) (Abdrabbo et al 2013). The obtained results are in line with tose obtained by Erdem et al (2006) on bean and El-Hendawy et al (2008) on maize. On the other hand, applying irrigation requirements by using drip irrigation in this study led to increase availability of the nutrient at root zone and increase the crop yield. (Al-Bakeir, 2003 and Medany et al 2009). Hegab et al (2014) studied the different irrigation requirement and irrigation level on faba bean; they found that using drip irrigation with proper irrigation application and proper sowing date led to increase the yield as well as enhance the yield component. 
Table 6. Effect of sowing dates, irrigation levels and their interactions on weight of ears per plant (g) and weight of 100 grains $(\mathrm{g})$ of maize hybrid at harvest at El-Bosaily Farm, Behira Governorate, as a combined of 2015 and 2016 growing seasons.

\begin{tabular}{|c|c|c|c|c|c|c|c|c|}
\hline \multirow{4}{*}{ Sowing dates (D) } & \multicolumn{8}{|c|}{ Combined of the two growing seasons } \\
\hline & \multicolumn{8}{|c|}{ Irrigation levels (I) } \\
\hline & \multicolumn{4}{|c|}{ Weight of ears per plant $(g)$} & \multicolumn{4}{|c|}{ Weight of 100 grains $(\mathrm{g})$} \\
\hline & $60 \%$ & $80 \%$ & $100 \%$ & Mean & $60 \%$ & $80 \%$ & $100 \%$ & Mean \\
\hline $1^{\text {st }}$ May & 211.1 & 247.7 & 286.8 & 248.5 & 36.37 & 41.86 & 45.17 & 41.13 \\
\hline $1^{\text {st }}$ June & 160.8 & 184.7 & 201.7 & 182.4 & 34.55 & 40.06 & 42.54 & 39.05 \\
\hline $1^{\text {st }}$ July & 122.8 & 138.3 & 146.8 & 136.0 & 22.88 & 25.10 & 32.38 & 26.78 \\
\hline Mean & 164.9 & 190.2 & 211.8 & 188.9 & 31.27 & 35.67 & 40.03 & 35.65 \\
\hline \multicolumn{9}{|c|}{ L.S.D $5 \%$} \\
\hline $\mathrm{D}$ & \multicolumn{4}{|c|}{6.49} & \multicolumn{4}{|c|}{1.88} \\
\hline 1 & \multicolumn{4}{|c|}{10.42} & \multicolumn{4}{|c|}{1.26} \\
\hline $\mathrm{DI}$ & \multicolumn{4}{|c|}{6.02} & \multicolumn{4}{|c|}{0.73} \\
\hline
\end{tabular}

Table 7. Effect of sowing dates, irrigation levels and their interactions on maize hybrid grain yield (ton/fed.) at harvest and water use efficiency $\left(\mathrm{kg} / \mathrm{m}^{3}\right)$ at El-Bosaily Farm, Behira Governorate, as a combined of 2015 and 2016 growing seasons.

\begin{tabular}{|c|c|c|c|c|c|c|c|c|}
\hline \multirow{4}{*}{$\begin{array}{l}\text { Sowing dates } \\
\text { (D) }\end{array}$} & \multicolumn{8}{|c|}{ Combined of the two growing seasons } \\
\hline & \multicolumn{8}{|c|}{ Irrigation levels (I) } \\
\hline & \multicolumn{4}{|c|}{ Grain yield /fed (ton/fed.) } & \multicolumn{4}{|c|}{ Water use efficiency $\left(\mathrm{kg} / \mathrm{m}^{3}\right)$} \\
\hline & $60 \%$ & $80 \%$ & $100 \%$ & Mean & $60 \%$ & $80 \%$ & $100 \%$ & Mean \\
\hline $1^{\text {st }}$ May & 2.63 & 3.23 & 3.98 & 3.28 & 1.82 & 1.68 & 1.66 & 1.72 \\
\hline $1^{\text {st }}$ June & 1.90 & 2.35 & 2.70 & 2.31 & 1.46 & 1.36 & 1.25 & 1.35 \\
\hline $1^{\text {st }}$ July & 1.37 & 1.64 & 1.84 & 1.62 & 1.31 & 1.17 & 1.06 & 1.18 \\
\hline Mean & 1.97 & 2.40 & 2.84 & 2.40 & 1.53 & 1.40 & 1.32 & 1.42 \\
\hline \multicolumn{9}{|c|}{ L.S.D $5 \%$} \\
\hline $\mathrm{D}$ & \multicolumn{4}{|c|}{0.10} & \multicolumn{4}{|c|}{0.06} \\
\hline 1 & \multicolumn{4}{|c|}{0.17} & \multicolumn{4}{|c|}{0.11} \\
\hline $\mathrm{DI}$ & \multicolumn{4}{|c|}{0.10} & \multicolumn{4}{|c|}{0.06} \\
\hline
\end{tabular}

3- Effect of sowing dates and irrigation levels on water use efficiency (WUE).

The highest WUE value was obtained by the early sowing date $\left(1^{\text {st }}\right.$ May); while the lowest WUE was obtained by the late ( $1^{\text {st }}$ July) sowing date as a combined of two growing seasons (Table 7). Water use efficiency (WUE) of maize was significantly responded by irrigation level treatments. In this respect the highest value of WUE was achieved by limited water irrigation $(60 \%$ of IR) treatments. Contrarily, the lowest WUE value was obtained from well-watered $(100 \% \mathrm{IR})$ treatment. Interpretation of such finding was reported by Abdrabbo et al (2013) who indicate that although irrigation water amounts of $100 \%$ and $80 \%$ (IR) gave the high- est vegetative growth and productivity per plant, the highest water use efficiency as the relative difference in the grain yield was compensated for by the relative difference in the seasonal amount of water which applied to the lowest irrigation water amount $60 \%$ of IR. Withal, the highest WUE was obtained by the lowest irrigation level; this maybe the advantage of use drip irrigation system. The frequency of proper water application by drip irrigation is one of the most important factors in drip irrigation management (Medany et al 2009). Due to the differences in soil water potential and soil water distribution with depth, grain yield and WUE might differ when the same quantity of water is applied under different irrigation level (El-Hendawy et al 2008). Therefore, it is essential to develop the 
most suitable irrigation level for different ecological regions, especially as plant water consumption during plant growth depends mostly on soil and climatic conditions (Nath et al 2001).

\section{REFRENCES}

Abdrabbo, M.A., Hashem, F.A., Maha, L. Elsayed, Farag, A.A., Abul-Soud, M.A., Maha, M. Hamada and Refaie, K.M. 2013. Evaluation of CSM-Ceres-Maize Model for simulating maize production in Northern Delta of Egypt Life Sci. J., 10(4), 3179 -3192.

Abdrabbo, M.A., Farag, A.A., Abul-Soud, M.A., Manal, M.H. Gad El-Mola, Fatma, S. Moursy, Sadek, I.I., Hashem, F.A., Taqi, M.O., ElDesoky, W.M.S. and Shawki, H.H. 2012. Utilization of satellite imagery for drought monitoring in Egypt. World Rural Observations., 4(3), 27-37.

Akbar, M., Saleem, M., Muhammad, F., Ashraf, M.K. and Ahmed, R.A. 2008. Combining ability analysis in maize under normal and high temperature conditions. J. Agric. Res., 64, 27-38.

Al-Bakeir, H.M. 2003. Yield, growth rate, and nutrient content of corn (Zea mays L.) hybrids. Hebron University Res. J., 1, 25-39.

Allen, R.G., Pereira, L.S., Raes, D. and Smith, M. 1998. Crop evapotranspiration. Guidelines for computing crop water requirements. FAO Irrigation and Drainage Paper No 56. FAO. Rome, Italy. 300 p.

Anonymous, 2015. Cultivation and management maize. Bulletin, 1343, 1-20.

Ayars, J.E., C.J. Phene, R.B. Hutmacher, K.R. Davis, R. A. Schoneman, S. S. Vail, and R.M. Mead. 1999. Subsurface drip irrigation of row crops: A review of 15 years of research at the Water Management Research Laboratory. Agric. Water Manage. 42, 1- 27.

Babiker, E.A. 1999. Effect of sowing date and plant density on growth and yield of irrigated maize (Zea mays L.) at Rahad (Sudan). University of Khartoum J. Agric. Sci., 7(1), 1-19.

Basu, S., Sharma, S.P. and Dadlani M. 2005. Effect of hydropriming on field emergence, crop performance and seed yield of maize parental lines during winter and spring-summer season. Seed Res. 33(1), 24-27.

Beiragi, M.A., Khorasani, S.K., Shojaei, S.H., Dadresan, M., Mostafavi, K. and Golbashy, M. 2011. A Study on effects of sowing dates on growth and yield of 18 corn hybrids (Zea mays L.). American J. Exper. Agric., 1(3), 110-120.

Campos, H., Cooper, M., Habben, J.E., Edmeades, G.O. and Schussler, J.R. 2004. Improving drought tolerance in maize: $A$ view from industry. Field Crops Res., 90, 1934.

Chapman, H.D. and Pratt, F. 1961. Methods of Analysis for Soils, Plants and Water. Univ. Calif. 35, 150-179,

Doorenbos, J., Pruitt, W.O., Aboukhaled, A., Damagnaz, J., Dastane, N.G., Van, Den, Berg, C., Rijtema, P..E. Asfor, O.M. and Frere, M., 1977. Crop Water Requirements: Irrigation and Drainage, FAO paper 24. Rome, Italy.

El-Hendawy, S.E., Abd El-Lattief, E.A., Ahmed, M.S. and Schmidhalter, U. 2008. Irrigation rate and plant density effects on yield and water use efficiency of drip-irrigated corn. Agric. Water Manage. 95, 836-844.

El-Marsafawy, Samia M., Hassanein, M.K. and Abdel-Salam, A.A. 2012. Studies on vulnerability of Egyptian maize varieties to future climatic changes. American-Eurasian J. Agric. \& Environ. Sci., 12(9), 1153-1161.

Erdem, Y., Seshril, S., Erdem, T. and Kenar, D. 2006. Determination of crop water stress index for simulating planting date effects on corn production using RZWQM and CERES Maize models. Agron. J., 17(97), 58-71.

FAO, 1982. Crop Water Requirements, Irrigation and Drainage. Paper No. 24, Rome, Italy.

Farag, A.A., Abdrabbo, M.A.A., El sharkawi, H.M. and Abou-Hadid, A.F. 2016. Comparison between SERE and RCP scenarios in Temperature and Evapotranspiration under Different Climate Zone in Egypt. IOSR J. Environ. Sci., 10(11), 54-64.

Farai, M., Albert, T.M. and Tafadzwanashe, M. 2015. Seed quality and water use characteristics of maize landraces compared with selected commercial hybrids. Chilean J. Agric. Res., 75 (1), 13-20.

Gaber, A.M. 2000. Water consumptive, water use efficiency and production of some wheat varieties. Egypt, J. Soil Sci. 40(4), 545-556.

Gerpacio, V.R. and Pingali P.L. 2007. Tropical and Subtropical Maize in Asia: production systems, constraints and research priorities. CIMMYT, Mexico, 93 p. http://repository.cimmyt.org/xmlui/bitstream/han dle/10883/800/90044.pdf?sequence $=1$ 

to Sowing Dates under North-Delta of Egypt Conditions

Gesch, R.W. and Archer, D.W. 2005. Influence of sowing date on emergence characteristics of maize seed coated with a temperatureactivated polymer. Agron. J. 97(6), 1543-1550.

Girardin, P. 1999. Ecophysiologie du mais. AGPM, 323, 135-191.

http://www.lavoisier.fr/notice/fr2900189410.html

Hegab, A.S.A., Fayed, M.T.B., Maha, M.A. Hamada and Abdrabbo. M.A.A. 2014. Productivity and irrigation requirements of fababean in North Delta of Egypt in relation to planting dates. Annals Agric. Sci., 59(2), 185-193.

Ibrahim, S.M. 1999. Wheat cultivation under limited irrigation and high water table conditions. Egypt. J. Soil Sci. 39(3), 361-372.

Israelsen, B.O. and Hansen, V.E. 1962. Irrigation Principles and Practices, $3^{\text {rd }}$ Ed. John Wiley and Sons, Inc., New York, USA, 447p.

Keller, J. and Bliesner, R.D. 1990. Sprinkle and Trickle Irrigation. AVI Book. Van Nostrand Reinhold, New York, 173p..

Medany, M.A., Attaher, S.M. and Abou-Hadid, A.F. 2009. Adaptation of agriculture sector in the Nile Delta region to climate change at farm level, International Symposium of Impact of Climate Change and Adaptation in Agriculture, 22-23 Aug. 2009, Vienna.
Medany, M.A., Hegazy, A.K., Kabiel, H.F. and Maez, M.M. 2007. Prediction of seed germination and seedling growth of crop plants as affected by root zone temperature. World J. Agric. Sci., 3(6), 714 -720.

Nath, R., Chakraborty, P.K. and Chakraborty, A. 2001. Effect of climatic variations on yield of sesame (Sesamum indicum L.) at different date of sowing. J. Agron. Crop Sci., 186, 97-102.

Oskouei, B., Hervan, E.M., Hamidi, A., Moradi, F. and Moghaddam, A. 2014. Effect of planting date on yield and germination indices of different shapes of hybrid maize seeds (Zea mays L. Cv. single cross 704). International J. of Biosciences (IJB) Sci., 5(12), 512-517.

Russelle, M.P., Olson, R.A. and Hauck, R.D. 1987. Planting date and nitrogen management interactions in irrigated maize. Field Crops Res., Amsterdam, 349-362.

Samuel, R.A., Scott, W.O. and Hoft, R.G. 1986. Modern Corn Production. $3^{\text {rd }}$ Ed., A\&L Publisher Inc., Illinois, USA,388 p.

Waller, R.A. and Duncan, D.B. 1969. A bayes rule for the symmetric multiple comparison problem. J. Am. Stat. Assoc Sci., 64, 1484 1504. 

المؤتمر الرابع عشر لبحوث التنمية الزراعية،

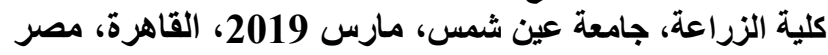

مجلا(27)، عدد(1)، عدلد خاص سبتمبر، 2019-289 2019، 2019

قياسات النمو والاحتياجات الإروائية وإنتاجية الذرة وعلاقتها بمواعيد الزراعة

تحت ظروف شمال الدلتا بمصر

[26]

أحمد صبرى أمين حجاب1"- محمد طاهر بهجت فايد² - مها متولى عباس حماده2 ـ

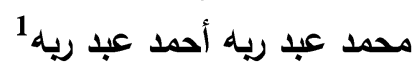

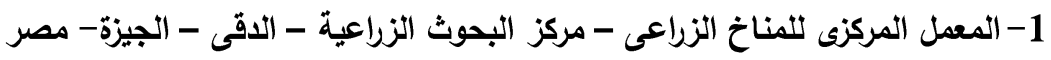

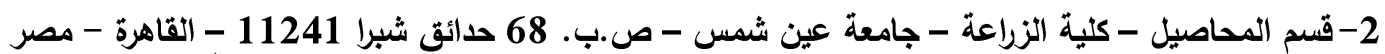

"Corresponding author: Ahmedsabry1988@yahoo.com

Received 11 December, 2018,

Accepted 8 January, 2019

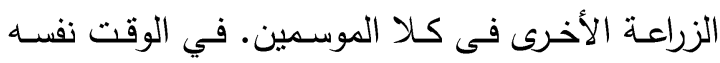

أدى مستوى الرى 60 \% من الإحتياجات الإروائية إلى الى

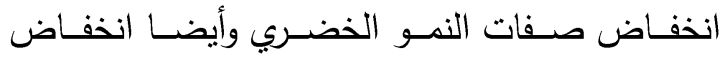

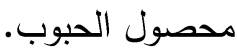

بينما أعطى مستوى الري 100 \% من الإحتياجات

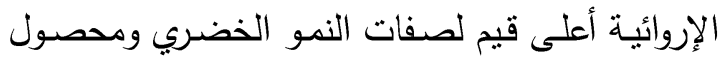

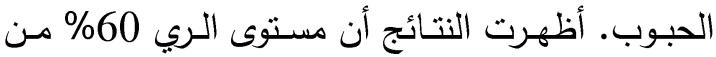

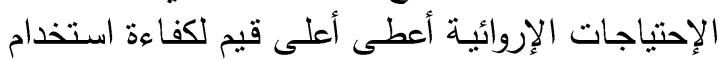

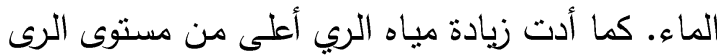

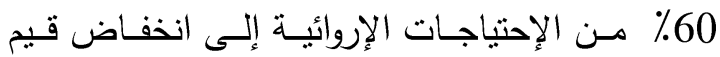

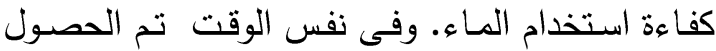

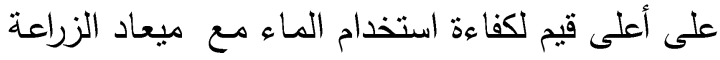
الأول (الأول من مايو) يليه تاريخ الزراعة الثاني لئن (الأول من يونيو)، بينما نم الحصول على الاولى أقل قيمة في ميعاد الزياد الزراعة الثالث (الأول من يوليو).

الكلمـات الدالة: الذرة الثـامية، صفات النمو الخضربي محصول الحبوب ومكوناته وكفاءة استخدام الماء الهاء التهات

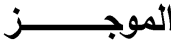

أقيمت الدراسة في محطة التجارب البحثية بمنطقة البوصيلى فى محافظـة البحيرة خـلال موسمى 2015 و2016 وذلك لدراسـة استجابة الذرة الثـامية (هجين الثين فردى 10) لثناثة مواعيد زراعة هى (أول مـايو، أول يونيو وأول يوليو ) وثلاثة مستويات ري هـى (60)

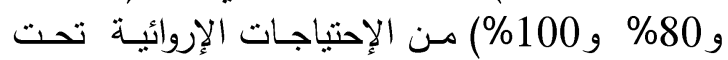

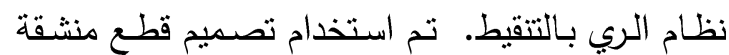

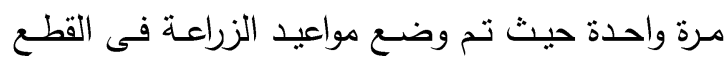
الرئيسية ومستويات الري فى القطع الفرعية. تم تقدير

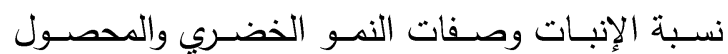

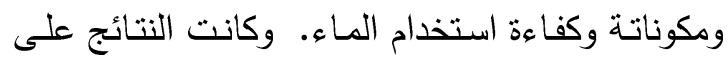
النحو التالي: أظهرت النتائج أنه بتأخير ميعاد الزراعة الناءت

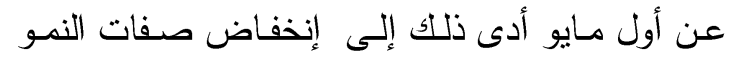

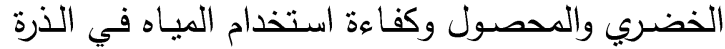
الثـامية. كما أعطى ميعاد الزراعة فيى أول يوليو أقل فئل

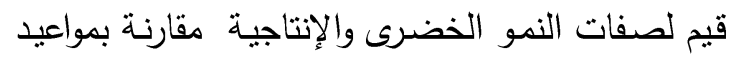

